\title{
The Africans and Asians in English Colonial Fiction: A Critical Analysis of Conrad's Heart of Darkness and Maugham's Footprints in the Jungle
}

\author{
Riyad Abdurahman Manqoush \\ Assistant professor of English literature, English Language Department \\ Hadhramout University, Yemen \\ riadmanqoush@yahoo.com
}

\begin{abstract}
The present paper is intended to analyze the representations of the Africans in Joseph Conrad's Heart of Darkness (1899) in comparison with the depictions of the Asians in William Maugham's Footprints in the Jungle (1933). Although both writers were born at the period of colonization and their works wrestle with the colonized natives, the research hypothesizes that Conrad (1857-1924) has an impact on Maugham (18741965). Since the analysis of the two stories is methodologically performed through a comparative paradigm, the parameter of the comparison, which will be the center of the discussions, is the strategy of representation. Therefore, the theoretical framework in this paper mainly depends on that strategy as discussed by Edward Said, Homi Bhabha, David Spurr, John McLeod and Bill Ashcroft. The study concludes that Conrad as a colonial writer has an obvious impact on Maugham, particularly in his representation of the colonized natives. However, though the Western colonial ideology seems to have an obvious effect on Conrad and Maugham, the latter is different from Conrad in the way he constructs the images and stereotypes. This is because Maugham's images of the natives seem to be true at least for Western readers whose knowledge of the different races in Malaya are not sufficient. In other words, it is difficult for them to differentiate between the factual depictions and deformations because Maugham gives more details that attract the attention of the reader and at the same time it can show how Maugham knows a lot about the natives in Malaya. This meticulous depiction differentiates Maugham from Conrad, who describes the Congolese natives generally.
\end{abstract}

Keywords: Representation; Conrad; Heart of Darkness; Maugham; Footprints in the Jungle.

\section{INTRODUCTION}

During the era of colonization, English fiction possessed a very political significance because it was the media that broadcast details about the colonized nations. This significance made authors pay a great deal attention to the process of representation in their narratives. The present paper is intended to analyze the representations of the Africans in Joseph Conrad's Heart of Darkness (1899) in comparison with the depictions of the Asians in William Maugham's Footprints in the Jungle (1933). Although both writers were born at the period of colonization and their works wrestle with the colonized natives, the research hypothesizes that Conrad (1857-1924) has an impact on Maugham (1874-1965). Since my analysis of the two stories will methodologically be performed through a comparative paradigm, the parameter of the comparison, which will be the center of the discussions, is the strategy of representation. Therefore, the theoretical framework in this paper will mainly depend on that strategy as discussed by Edward Said, Homi Bhabha, David Spurr, John McLeod and Bill Ashcroft.

\section{LiteratURE REVIEW}

Since the present research is a comparative study between two authors' literary productions, my survey of the previous scholarly research includes scholarly studies on Conrad's Heart of Darkness and also on Maugham's Footprints in the Jungle. Due to the limitation of space in this paper, I have merely selected the critiques that are more relevant.

Isam Shihada (2014:10) investigates "how Conrad's Heart of Darkness has played an important role in exposing the brutal reality of Belgian colonialism of the Congo Free State under the pretence of a civilizing mission." This is because the events in the novella uncover the inhuman treatment practised by the European colonizers against the Congolese natives. In other words, Shihada (2014:10) analyzes 
the novella with a special historical emphasis on the "atrocities committed by King Leopold II's agents in their desperate scramble for the rich resources of Congo like ivory and rubber". Shihada (2014:10) also adds that:

King Leopold II's atrocities may account for the death of almost ten million Congolese natives, a crime of a genocidal scale which has terribly affected the future of the Congo and its people till today. Conrad renders his own anticolonial critique through his central character, Charles Marlow who learns about the brutal methods of Belgian colonialism while he is on a journey to the Congo searching for the infamous, ivory agent, Kurtz.

This indicates that Conrad's Heart of Darkness is a metafiction that criticizes history. Its critical view is clearly seen when Shihada (2014:10) "concludes how Conrad's Heart of Darkness critique of King Leopold II's colonial rule has contributed to the launching of international protest campaign that strives to expose, and put an end to the inhuman genocide committed against the Congolese natives in the name of civilization, science and progress." According to Shihada (2014:10), this "campaign" was the reason that "forced King Leopold II to quit the Congo Free State in 1908 paving the way for uncovering one of the most heinous crimes in history committed in the name of so called civilization." In fact, Shihada's article, which examines the narrative in relation to history, differs from the present research that investigates Conrad's Heart of Darkness with an intention to confirm its effect on Maugham's Footprints in the Jungle.

In addition to that, Latef Nooriberzenji \& Marwan Abdi (2013:710) investigate "two opposing images of African culture presented in both novels: Conrad's Heart of Darkness and Achebe's Things Fall Apart." Their research ends up with the finding below:

Heart of Darkness depicts Africans as marginalized, voiceless and primitive, which is considered by many critics as an indictment of the hypocritical civilizing mission of the Europeans; whereas Achebe's Things Fall Apart repudiates the cultural assumptions presented by Conrad and delineates a totally different image of the African society in the process of change, which is aware of its past history and strives to control its future. (Nooriberzenji \& Abdi 2013:710).

In other words, while Conrad misrepresents the Africans, Achebe resists the European misrepresentations of Africans. Unlike Nooriberzenji \& Abdi's paper, which provides a contradictory representations about the natives by Conrad and Achebe, the current study exposes the resonance of Conrad on Maugham, and also how the latter diverges from Conrad.

Just like Conrad's Heart of Darkness, Maugham's Footprints in the Jungle has also been analyzed by some scholars. For instance, Majed Hamed Aladaylah (2012:1) probes Footprints in the Jungle with the aim of examining "Maugham's depictions of non-white communities-Malay, Chinese and Indian." The study explores how Maugham as a "colonialist writer reinforced and spread the idea of physical and social differences between the Europeans and the non-European races, rendering the latter an inferior position to the former" (Aladaylah 2012:1). This is probably because, as I will explain afterward in the next sections, Maugham's depiction depends on the binary oppositions between the Europeans and the natives. This division leads Aladaylah (2012:1) to wrap up his research with the notion that "Maugham's narrative represents the Eastern social and cultural practices in an unpalatable manner. For example, the geography and landscape of the colonized territory is sketched as evil, savage, dark, et cetera." In the present paper, I attempt to fill in the gap of Aladaylah's article by inspecting the reasons beyond Maugham's distorted images of the natives. This is because, as I will discuss later on, Maugham, as a European, was influenced by the colonial ideology, and as an author, he was affected by Conrad.

By the same token, Siti Nuraishah Ahmad (2014:49) "examines spatial images in British fiction through the framework of archetypal literary criticism and theories of colonial representations of space to reveal the worlding of Malaysia as a garden." The research concentrates on the works of "Joseph Conrad, W. Somerset Maugham, and Anthony Burgess" (Ahmad 2014:49). Ahmad (2014:49) ends up her article with the conclusion that "the representation of Malaysia in various guises of the archetypal garden negates the indigenous worldview concerning space and produces instead 
The Africans and Asians in English Colonial Fiction: A Critical Analysis of Conrad's Heart of Darkness and Maugham's Footprints in the Jungle

knowledge about Malaysia rooted in the white man's perspective." This kind of "representation" is always negative or exotic.

In short, Conrad's Heart of Darkness and Maugham's Footprints in the Jungle have been discussed in different scholarly writings. However, none of the previous discussed critiques have examined the two stories with the purpose of uncovering the effect of one on the other, and also the convergences and divergences between them.

\section{TheORETICAL FraMeWORK}

John McLeod (2000:21) argues that Western nations like France and Britain spent an immense amount of producing knowledge about locations they colonized. This argument copes with the claims of Edward Said (1995:1) that when those "European visitors" came to the East, their duty was a "representation of the Orient". In other words, Said (1995:2) alleges that "the Orient was almost a European invention, and had been since antiquity a place of romance, exotic being, haunting memories and landscapes, remarkable experiences." This means what people's knowledge of the colonized nations and lands depended merely on the media of the colonial West. This makes scholars and theorists suspect the Western colonial West because its representation can be appropriated and probably deformed. As a result, David Spurr (1993:28) claims that the Western representation of the East is a kind of "appropriation". He argues that "appropriation is put forth most explicitly in the writings of European colonial administrators who saw the natural resources of colonized lands as belonging rightfully to civilization and mankind rather than to the indigenous peoples who inhabited those lands" (Spurr 1993:28). In fact, the words of "civilization and mankind" are used by Spurr to refer to the Europeans. This is indeed because the Europeans at that time were preoccupied by a "colonial discourse", which sheds light on the necessity of "the preservation of colonial rule, as well as the exploitation of colonized territories" (Spurr 1993:29). This colonial ideology is clearly explained when Spurr (1993:31) states that "the colonizing imagination takes for granted that the land and its resources belong to those who are best able to exploit them according to the values of a Western commercial and industrial system". This ideology amplifies the sense of hierarchy that dominated the Europeans in the last centuries and it also legitimizes their colonization of many countries in the East. Therefore, there is a big relation between the "colonial discourse" and the process "fixity" as Homi Bhabha illustrates in the excerpt below:

An important feature of colonial discourse is its dependence on the concept of fixity in the ideological construction of otherness. Fixity, as a sign of cultural/historical/racial difference in the discourse of colonialism, is paradoxical mode of representation: it connotes rigidity and an unchanging order as well as disorder, degeneracy and daemonic repetition. (Bhabha 1994:66).

While describing the natives in the East, Western writers fix some portrayals in their works. Most of these portrayals are negative. In fact, Bhabha elsewhere utilizes the word "stereotype" as a synonym of "fixity". For instance, he explicates that "the stereotype, which is its major discursive strategy, is a form of knowledge and identification that vacillates between what is always in place, already known, and something that must be anxiously repeated" (Bhabah 1994:66). This coincides with McLeod's explication that the "Oriental stereotypes fixed typical weakness as (amongst others) cowardliness, laziness, untrustworthiness, fickleness, laxity, violence and lust" (2000:46). In fact, the repetitions of these images usually lead to showing the Eastern natives as degenerate, backward and savages. These images are also intended to legitimize the European invasion of the East. McLeod (2000:46) highlights that the "Oriental peoples were often considered as possessing a tenuous moral sense and the readiness to indulge themselves in the more dubious aspects of human behaviour." The European diffusion of stereotypes about the East has been discussed by Said under the term of "manifest Orientalism" that refers to "the various stated views about Oriental society, languages, literatures, history, sociology, and so forth" (Said 1995:206). In addition to that, McLeod (2000:46) argues that by "creating these stereotypes, Orientalism justified the propriety of colonialism by claiming that the Oriental peoples needed saving from themselves." The dispersal of the stereotypes can be more perilous when the natives are not aware of the ideologies operated behind them i.e. they may accept the stereotypes without seriously testing them.

In addition to propagating stereotypes about them, the natives and their cultures can possibly be exoticized. The term "exoticisation" is a synonym of "exoticism" from which the adjective "exotic" is derived. Bill Ashcroft et al. (2007: 87), alleges that "the word exotic was first used in 1599 to mean 
'alien, introduced from abroad, not indigenous'. By 1651 its meaning had extended to include 'an exotic and foreign territory', 'an exotic habit demeanour'." According Said (1995:1), the West sees the Orient as "a place of romance, exotic beings, haunting memories and landscapes, remarkable experiences." In other words, the West relates the bizarre tales to the East. In fact, Western writers may exoticize the natives in their works to attract the attention of their audience, or as Said (1995:336) alleges, because their works are "designed for readers and consumers in the metropolitan West", not for Oriental readers.

The Western representation is sometimes intended to reject and deny the natives and their culture. This "rejection" is also used under the name of "abrogation" by Ashcroft et al. (2007:3). Similarly, the same concept is utilized by Spurr under the "strategy of negation". Spurr (1993:92) highlights "the rhetorical strategy of negation by which Western writing conceives of the Other as absence, emptiness, nothingness, or death." Since this denial and rejection is a step towards colonization, the "colonized people are systematically represented in terms of negation and absent" (Spurr 1993:96). The "negation" can sometimes be covert. For instance, many colonial writings concentrate on Western characters and ignore the natives, and in case there are natives in the narrative, those natives have no voice to express themselves and culture. In addition to that, some colonial writers utilize the natives and their cultures to make binary oppositions between the West and East. Spurr (1993:62) discusses the use of binary opposition under the concept of "classification" which he defines "as a rhetorical procedure by which Western writing generates an ideologically charged meaning from its perceptions of non-Western cultures." In other words, "classification" can be a "rhetorical opposition between civilized and savage" people (Spurr 1993:67). This indicates that the world is always in binary oppositions or divisions, particularly between the Western colonizer and the colonized Orient; "each is assumed to exist in opposition to the other" (McLeod 2000:40). According to McLeod (2000:41), "the Orient is frequently described in a series of negative terms that serve to buttress a sense of the West's superiority and strength." For instance, "the West" is repeatedly portrayed "as the seat of knowledge and learning," while "the Orient is the place of ignorance and naiveté" (McLeod 2000:41). Western writings utilize this classification to differentiate between the Occident and the Orient. When the Orient is depicted as uncivilized, the West is alternatively represented as civilized.

In next section, I will use this theoretical background to examine Conrad's representation of the Africans in Heart of Darkness, and comparing it with Maugham's depiction of the Asians in Footprints in the Jungle. This is because although both converge in using the strategy of representation in their narratives, their style diverges especially in the depth and precision.

\section{DiscuSSION AND ANALYSIS}

Since the paper is a comparative study between the portrayals of the Africans in Conrad's Heart of darkness and the depictions of Asians in Maugham's Footprints in the Jungle, the analysis is accordingly divided into two main sections as shown below:

\subsection{The Africans in Conrad's Heart of Darkness}

Heart of Darkness centers on Marlow who leaves England and travels to the Congo to receive his new job as a riverboat captain and at the same time to search for Kurtz, the chief of the Inner Station. In his voyage through the Congo River, Marlow passes through some villages of the Congolese natives. He witnesses the Western ivory agents' brutal treatment against the natives. However, Marlow himself, as a protagonist and narrator, describes the Congo in a way that gives a negative impression about it. For instance, he states that:

I was smoking my pipe quietly by my dismantled steamer, and saw them all cutting capers in the light, with their arms lifted high, when the stout man with mustaches came tearing down to the river, a tin pail in his hand, assured me that everybody was 'behaving splendidly, splendidly,' dipped about a quart of water and tore back again. I noticed there was a hole in the bottom of his pail. (Heart of Darkness, p.27).

Reading this description, one can think that the narrator travelled to a pre-historical land where people are childish and ignorant. As the narrator portrays, the natives were "all cutting capers in the light, with their arms lifted high". In fact, "cutting capers" means dancing in a childish way and putting their hands up while dancing. This is one of the stereotypical images that are attached to the indigenous people in Africa and other lands in the East. In addition to that, the same excerpt shows 
the natives as dim-witted. This is evidently seen when Marlow watches a Congolese carrying "a tin pail" in his hand and he goes many times to the river to fill the "pail" with water but, while he walks, the pail empties because it has a "hole" in its "bottom". The native repeats the same action many times and knows nothing about the reason why the pail becomes empty. This humorous portrait is unquestionably intended to highlight the ignorance and foolishness of the natives.

By the same token, the Congolese are negated and dehumanized in Heart of Darkness. This negation and dehumanization can obviously be seen in the characters of the boy and other natives, whom Marlow witnesses when he passes near their village, as quoted below:

Near the same tree two more bundles of acute angles sat with their legs drawn up. One, with his chin propped on his knees, stared at nothing, in an intolerable and appalling manner: his brother phantom rested its forehead, as if overcome with a great weariness; and all about others were scattered in every pose of contorted collapse, as in some picture of a massacre or a pestilence. (Heart of Darkness, p.21).

Marlow metaphorically portrays the natives as "bundles of acute angles". This metaphor circuitously negates the natives to expose them as inhuman. The narrator also describes the way those natives sit when he said: they "sat with their legs drawn up". Although the sketch of the "legs" sounds to be ambiguous, the verb "sat" shows that Marlow pictures human beings. This reinforces my previous claim that the narrator uses the noun phrase "bundles of acute angles" to refer to the Congolese villagers. The image becomes clearer when Marlow gives more detail about the villagers. He adds that "One, with his chin propped on his knees, stared at nothing, in an intolerable and appalling manner". The excerpt contains a paradox between the boys' attention and Marlow's claim that they "stared at nothing". This paradox apparently shows a binary opposition between the behavior of the Europeans and Africans. On one hand, the contrast highlights the hierarchy of the European colonizers. On the other hand, it negates the Africans. This negation is perceptible when Marlow tells the boy's "brother" is "phantom rested its forehead". The protagonist's use of the possessive adjective "its" uncovers the narrator's colonial ideology and it also reveals his adoption of a negative attitude toward the Africans. The image becomes visible when the protagonist adds that:

While I stood horror-struck, one of these creatures rose to his hands and knees, and went off on all-fours towards the river to drink. He lapped out of his hand, then sat up in the sunlight, crossing his shins in front of him, and after a time let his woolly head fall on his breastbone. (Heart of Darkness, p.21).

The narrator utilizes the word "creatures" to refer to the Congolese villagers. In his narration about one of the villagers who was so thirsty, the protagonist indicates that the villager "went off on allfours towards the river to drink". The term "on all-fours" is usually used by people when they speak about animals and beasts. Nevertheless, this portrayal is now and again used in the novella to negate the Congolese natives. For instance Marlow narrates that:

And between whiles I had to look after the savage who was fireman. He was an improved specimen; he could fire up a vertical boiler. He was there below me, and, upon my word, to look at him was as edifying as seeing a dog in a parody of breeches and a feather hat, walking on his hind-legs. A few months of training had done for that really fine chap (Heart of Darkness, p.37).

Marlow employs the word "savage" while he speaks about the Congolese "fireman" who accompanies him on the boat. Thus, even though this African man works with the European colonizers, he is misrepresented. Yet, Marlow slightly differentiates the fireman from the other natives by calling him "an improved specimen". However, even though Marlow privileges the fireman, he is also shown as human-like. Furthermore, the narrator continues to misrepresent the natives in the same except quoted above. The simile in the last three lines shows the native as a "dog" dancing "in a parody of breeches and a feather hat, walking on his hind-legs". This depiction contributes in broadening the gap between the British colonizers and the colonized Africans. In other words, it reinforces McLeod's argument, which has been discussed earlier, that the Western representation of the East constructs a binary opposition between the Orient and the Occident 
(2000:40). This division uncovers the colonial ideology that focuses on the hierarchy of the colonizers and the backwardness of the natives. Being influenced by this ideology, Conrad deforms the colonized Congolese.

\subsection{The Asians in Maugham's Footprints in the Jungle}

Maugham's Footprints in the Jungle is a detective story about the Europeans who lived in Malaya during the period of the British colonization i.e. from the eighteenth century until the early twentieth century. Those Europeans were amazed with Malaya's beauty as reflected at the beginning of the story and quoted below:

There is no place in Malaya that has more charm than Tanah Merah. It lies on the sea, and the sandy shore is fringed with casuarinas. The government offices are still in the old Raad Huis that the Dutch built when they owned the land, and on the hill stand the grey ruins of the fort by aid of which the Portuguese maintained their hold over the unruly natives. (Footprints in the Jungle, p.639).

This description exoticizes the city of Tanah Merah that "lies on the sea" and also "the sandy shore" that "fringed with casuarinas". In addition to that, the story mentions the different European colonizers who occupied Malaya: the Dutch, Portuguese and the British. However, the narrator's depiction of the Malays sounds to be biased for he addresses them as "the unruly natives". The word "unruly" indicates that the "natives" behave against the law, but in reality this image was probably created in the text because the natives do not obey their colonizers. The natives can be "unruly" in the eyes of their colonizers but this unruliness can be considered as resistance among the local people. Since those natives do not have the power that enables them to resist their European invaders, they resist their colonizers by disobeying their orders and regulations. The natives sometimes refuse to work under the commands of their colonizers and this reaction can be seen as a sign of rebellion.

By the same token, Footprints in the Jungle highlights the lost identity of the Chinese who live in Malaya. For instance, the "Chinese merchants", as the narrator explains, "have forgotten their native language and hold intercourse with one another in Malay and pidgin English" (Footprints in the Jungle, p.639). On one hand, this manifestation indicates that the Maugham is quite aware of the Malayan history and people. On the other hand, it can be seen as a kind of biasness against those Chinese who came to Malaya centuries ago and they now consider themselves as the local people in Malaya after changing its name into Malaysia.

As discussed earlier, Conrad makes a binary opposition between the Europeans and the Congolese to expose the hierarchy of the West and its people. This attitude is also echoed by Maugham in Footprints in the Jungle when the narrator of the story describes that "the European quarter is very silent. It is trim and neat and clean" (Footprints in the Jungle, p.639). The narrator in this excerpt draws a positive picture about the Europeans in Malaya. As he claims, their "quarter is very silent". He also uses words like "trim", "neat" and "clean". All these adjectives are not only intended to depict the "European quarter" but also to prove the hierarchy of the Europeans. In other words, the narrator wants to say that the Europeans are civilized. However, this discourse develops into a kind of prejudice when the narrator identifies those Europeans as "white men". For example, according to the narrator, "the houses of the white men-government servants and agents of companies-stand round an immense padang, ..." (Footprints in the Jungle, p.639). Using the conception "white men" to refer to the Europeans reveals that the non-Europeans are black or at least colored. In other words, the portrayal here makes a difference between the Europeans and the natives even in their colors.

Likewise, Maugham in Footprints in the Jungle attempts to expose the East as an exotic place that is different from the West. For instance, in his description of Mrs. Cartwright, the narrator tells that "she was a woman somewhere in the fifties (though in the East, where people age quickly, it is difficult to tell their ages)" (Footprints in the Jungle, p.640, brackets original). Representing the East as a place "where people age quickly, it is difficult to tell their ages" may astonish the readers and it probably gives them an impression that the East is an extraordinary land. This viewpoint is repeated in the story now and again. For instance while the narrator speaks with Gaze about Mrs. Cartwright, Gaze says: "You haven't lived out East all your life. It ages one before one's time. One's an elderly man at fifty and at fifty-five one's good for nothing but the scrap-heap" (Footprints in the Jungle, p.643). This sort of description is exotica for those who know the East very well. In fact, the East is not a small 
place; what exists in the Malay Archipelago may not exist in China or India. The weather, nature, economic problems are different from one country to another. Just like Conrad, Maugham overgeneralizes some of the stereotypes and images to the whole East. This similarity confirms that Conrad has a stylistic effect on Maugham particularly in his portrayal of the colonized natives.

Although Conrad has an obvious influence on Maugham, the latter's representation of the East especially the Malays in Footprints in the Jungle is dubious. It is difficult to decide whether he exoticizes them or fairly represents them. For instance, when the narrator asks Gaze whether he suspects the Malay coolies to have murdered the European, Gaze replies: "No, they wouldn't have the nerve. I think a pair of Chinks might think out a trick like that, but I don't believe Malay would. They'd be much too frightened" (Footprints in the Jungle, p.650). In fact, the word "frightened" can be understood as peaceful and easygoing, and at the same time, it can be perceived as cowards who fear everything. In addition to that, this is paradoxical when comparing it with the narrator's previously discussed depiction in which he describe the Malays as "unruly" (Footprints in the Jungle, p.639). The ambiguity grows when Gaze tells somewhere else in the story that "the Malays are used to keeping things tucked away in their sarongs, and the Chinese have pockets in their coats" (Footprints in the Jungle, p.655). In fact, one can accept this depiction because it sounds real, but this recognition seems to be devious, particularly when reading Gaze's other description. Gaze adds that "the Malays are an extravagant race and a race of gamblers, and the Chinese are gamblers, too; sooner or later someone would start flinging his money about, and then I should want to know where it came from" (Footprints in the Jungle, p.453). This portrayal uncovers Maugham's colonial discourse for the Malays are stereotyped as "extravagant and gamblers". The latter stereotype has simultaneously been labeled to the Chinese. It seems that Gaze wants to deliver a message beyond these stereotypes - exposing the Malays and Chinese as illegally earned their money. This voice is apparent when he says "I should want to know where it came from". The sentence gives the notion that the Malays and Chinese are thieves. Being influenced by the colonial ideology and Conrad, Maugham gives himself the right to represent the Malays and the Chinese, and subsequently this leads him to construct negative stereotypes about them.

\section{CONCLUSION}

Based on my analysis Conrad's Heart of Darkness and Maugham's Footprints in the Jungle, I can conclude that Conrad as a colonial writer has an obvious impact on Maugham, particularly in his representation of the colonized natives. This can be seen through the similarities that exist in their texts. In both narratives, the Europeans are narrators, protagonists or at least main characters. The natives, on the contrary, are minor characters, marginalized and voiceless. For instance, Conrad's portrayal of the natives in the Congo is resplendent with misrepresentation and dehumanization. Similarly, Maugham represents the natives in Malaya in negative stereotypes and sometimes he makes binary oppositions between the natives and the Europeans. In general, both Conrad and Maugham deform and dehumanize the natives to publicize the hierarchy and superiority of the Europeans. However, though the Western colonial ideology seems to have an obvious effect on Conrad and Maugham, the latter is different from Conrad in the way he constructs the images and stereotypes. This is because Maugham's images of the natives seem to be true at least for Western readers whose knowledge of the different races in Malaya are not sufficient. In other words, it is difficult for them to differentiate between the factual depictions and deformations because Maugham gives more details that attract the attention of the reader and at the same time it can show how Maugham knows a lot about the natives in Malaya. This meticulous depiction differentiates Maugham from Conrad, who describes the Congolese natives generally.

\section{REFERENCE}

[1] Conrad, J. (2014). Heart of Darkness. USA: Pestwick House.

[2] Maugham, W. S. (1976). Footprints in the Jungle. In Sixty-Five Short Stories. London: Octopus Books Limited, pp.639-658.

[3] Shihada, I. M. (2014). Historicizing Joseph Conrad's "Heart of Darkness": a critique of King Leopold II's colonial rule, International Journal of English Language, Literature and Translation Studies, vol.1, no.3, pp.10-21. 
[4] Nooriberzenji, L. \& Abdi, M. (2013). The image of the Africans in Heart of Darkness and Things Fall Apart, Interdisciplinary Journal of Contemporary Research in Business, vol.5, no.2, pp.710-726.

[5] Aladaylah, M. H. (2012). Postcolonial reading of a colonial text. vol.5. no.9, pp.122-126.

[6] Siti Nuraishah Ahmad. (2014). Malaysia as the archetypal garden in the British creative imagination. Southeast Asian Studies, vol. 3, no. 1, pp.49-84.

[7] McLeod, J. (2000). Beginning Theory. USA: Manchester University Press.

[8] Said, E. (1995). Orientalism. London: Penguin Groups

[9] Spurr, D. (1993). The rhetoric of empire: colonial discourse in journalism, travel writing, and imperial administration. London: Duke University Press.

[10] Bhabha H. K. (1994). The Location of Culture. London: Routledge.

[11] Ashcroft, B., Griffiths, G. \& Tiffin, H. (2007). Post-colonial studies: the key concepts. New York: Routledge.

[12] Manqoush, R. (2015). The cultural dilemma of the Yemeni and Chinese migrants: Mohammad Abdulwali's They Die Strangers vs. Amy Tan's The Joy Luck Club, vol.3, no.6, pp.461-471.

\section{AUTHOR's BIOGRAPHY}

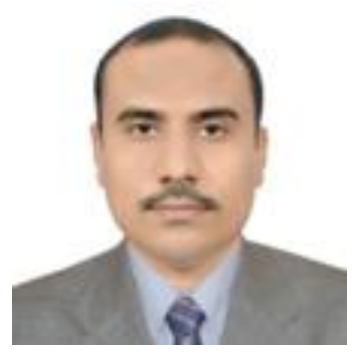

Riyad Abdurahman Manqoush, Ph.D, teaches English literature at English Language Department, Faculty of Education in Seiyun, Hadhramout University, Yemen. In 2008, he received his MA in English literature (PostColonial Literature in English) from National University of Malaysia. In 2011, he received his Ph.D. in English literature (Comparative Literature) from the same university. His research areas are postcolonial theory, comparative literature, diaspora writings, literary criticism and the theory of intertextuality. 